\title{
A modified rapid slide test for anti-streptolysin $\mathrm{O}$
}

\author{
G. B. P. INGRAM AND J. E. P. HUGHES \\ From the Laboratory, South Tyrone Hospital, Dungannon, Co. Tyrone
}

SYNOPSIS This paper describes the modification of a commercially available rapid slide screening test $^{1}$ for anti-streptolysin $O$ to give quantitative results. The modified technique is compared with the long-established haemolytic technique of Rantz and Randall (1945).

The quantitative results for both techniques are shown to be comparable. The modified slide test offers the advantage of saving time and labour.

\section{Materials and Methods}

Sera submitted to this laboratory for anti-streptolysin $O$ titres from 100 patients were analysed by the Rantz and Randall haemolytic technique, and our modification of the rapid slide screening test (Behringwerke).

Reduced streptolysin $\mathrm{O}$, with a potency of 2 International Unit equivalents per $\mathrm{ml}$, purchased from Wellcome Reagents Ltd, was used in the Rantz and Randall method. The technique detailed in the instructions with the package was strictly adhered to. Each batch of tests were controlled by using an anti-streptolysin $\mathrm{O}$ also purchased from Wellcome Reagents Ltd.

The total incubation time for this method is one hour. The last dilution tube showing no haemolysis, indicating that the streptolysin $\mathrm{O}$ which has been added is neutralized by the anti-streptolysin $O$ in the patient's serum, is taken as the end point.

The rapid slide screening test (Behringwerke Latex-ASL) was designed by the manufacturers as a qualitative screening test to detect those sera showing a significant increase in anti-streptolysin $O$ (more than $200 \mathrm{iu} / \mathrm{ml}$ ). In its original form, $0 \cdot 1 \mathrm{ml}$ of the test serum is incubated with $0.3 \mathrm{ml}$ of the streptolysin $\mathrm{O}$ supplied at room temperature for 15 minutes. One volume of this dilution is then mixed with 1 volume of a sensitized latex suspension on a glass slide, and examined for macroscopic agglutination after gentle rocking for approximately four to six minutes. Sera showing distinct agglutination are interpreted as having anti-streptolysin $O$ levels of 200 iu per $\mathrm{ml}$ or more.

We have modified this method to provide a quantitative anti-streptolysin $\mathrm{O}$ titre.

${ }^{1}$ Behringwerke Latex-ASL, Hoechst Pharmaceuticals Ltd.

Received for publication 26 January 1972.

\section{Modified Rapid Slide Test}

1 Ten $\mathrm{ml}$ of isotonic saline is added to the vial of streptolysin $O$ supplied instead of $5 \mathrm{ml}$ as recommended by the manufacturer.

2 Serial dilutions of the patient's serum are made as follows:

\begin{tabular}{|c|c|c|c|c|c|c|}
\hline & \multicolumn{6}{|c|}{ Tube No. } \\
\hline & 1 & 2 & 3 & 4 & 5 & 6 \\
\hline $\begin{array}{l}\text { Streptolysin O (vol.) } \\
\text { Patient's serum }\end{array}$ & 3 & 6 & 9 & 12 & 15 & 18 \\
\hline $\begin{array}{l}\text { (vol.) } \\
\text { Final titre (iu/ml) }\end{array}$ & $\begin{array}{r}1 \\
100\end{array}$ & $\begin{array}{r}1 \\
200\end{array}$ & $\begin{array}{r}1 \\
300\end{array}$ & $\begin{array}{r}1 \\
400\end{array}$ & $\begin{array}{r}1 \\
500\end{array}$ & $\begin{array}{r}1 \\
600\end{array}$ \\
\hline
\end{tabular}

3 Each dilution is mixed and incubated at $37^{\circ} \mathrm{C}$ for 15 minutes.

4 One volume of each dilution is mixed on a glass slide with 1 volume of the latex suspension, rocked gently for two minutes, and examined for macroscopic agglutination.

The weakest dilution showing agglutination is interpreted as being the end point of the titre.

Further dilutions of the patient's serum may be made to determine the final titre in those sera showing strong agglutination with the dilution containing 600 iu per $\mathrm{ml}$ of streptolysin $\mathrm{O}$. In our experience only $15 \%$ of sera submitted for antistreptolysin $\mathrm{O}$ estimation have a titre exceeding 600 iu per ml.

In our experience the recommendation of the manufacturers of incubation at room temperature and a long mixing time made the slide test oversensitive. More comparable results were achieved between the modified slide test and the Rantz and Randall method by incubating the patient's serum/ anti-streptolysin $\mathrm{O}$ mixture at $37^{\circ} \mathrm{C}$ and mixing with the latex particles for two minutes on a glass slide. 


\section{Results}

For the purpose of comparing the two methods as closely as possible we made dilutions of the patient's sera so that the final titre rose in steps of 50 in our modified slide test. The titre results of this method were interpreted as agreeing with the titre results of the Rantz and Randall haemolytic method if they fell within plus or minus 1 tube dilution of the Rantz and Randall titre. The results are summarized in Table I.

\begin{tabular}{llll}
\hline $\begin{array}{l}\text { Rantz and } \\
\begin{array}{l}\text { Randall Titres } \\
\text { (iu) }\end{array}\end{array}$ & No. of Sera in Agreement & $\begin{array}{l}\text { No. of Slide Test } \\
\text { Results }\end{array}$ \\
\cline { 2 - 4 } & $\begin{array}{l}\text { Rantz and } \\
\text { Randall }\end{array}$ & $\begin{array}{l}\text { Modified Slide } \\
\text { Test }\end{array}$ & $\begin{array}{l}\text { Outside } \pm \text { Tube } \\
\text { Dilution }\end{array}$ \\
\hline 50 & 17 & 17 & 0 \\
100 & 5 & 5 & 0 \\
125 & 13 & 13 & 0 \\
166 & 17 & 16 & 1 \\
250 & 9 & 9 & 0 \\
333 & 11 & 5 & 6 \\
$>333$ & 28 & 28 & 0 \\
Total no. of sera & 100 & 93 & 7
\end{tabular}

Table I Comparison of results between Rantz and Randall and modified slide tests

Thirty-five sera had titres in the normal range up to $125 \mathrm{iu}$ and 28 sera had significantly raised levels of anti-streptolysin $\mathrm{O}$, ranging from 333 to $1,250 \mathrm{iu}$ per $\mathrm{ml}$, by the Rantz and Randall method. The titre levels obtained by the modified slide test were similar in all cases in both these groups.

A further 37 sera had haemolytic titres in the 'borderline significant' range of 166 to 333 iu per ml of anti-streptolysin $\mathbf{O}$. In this group the titre result

\begin{tabular}{ll}
\hline Rantz and Randall Titre & Modified Slide Test Titre \\
\hline 166 & 350 \\
333 & 100 \\
333 & 100 \\
333 & 100 \\
333 & 100 \\
333 & 100 \\
333 & 700 \\
\hline
\end{tabular}

Table II Actual titres of sera not agreeing within \pm 1 tube dilution was higher in two sera with the modified slide test than that obtained from the Rantz and Randall 을 method and lower in five cases. The actual titres obtained in these seven discrepant results are shown in Table II.

\section{Discussion}

The value of a rising or elevated anti-streptolysin 0 \% titre in aiding the diagnosis of recent streptococcal $\vec{O}$ infection has been well established. Patients suspected of having this infection usually have two or more sera analysed at intervals of one week to check for a rising titre. The discrepancies noted between the two techniques in this series should then be o shown to have little significance on subsequent 9 examination. The five false negative and two addi- is tional positive results obtained by the modified slide $\omega$ test may have been due to dilution error, although it $\frac{\rho}{?}$ is possible that in the latter two cases non-specific streptolysins may have caused the Rantz and Randall haemolytic titre to be falsely low.

The modified latex slide test described in this paper has several advantages over the conventional haemolysis test. Apart from the variances usually associated with a haemolytic indicator system, such as concentration of the red cell suspension, the Rantz and Randall technique may be affected by non-specific streptolysins such as $\beta$-lipoproteins. The slide test is not affected by these non-specific substances. The total time required to complete the conventional haemolysis test is 75 minutes, including an incubation period of 60 minutes. The modified slide test can be completed in 20 minutes, including an incubation period of 15 minutes.

The modified slide test described is a valuable and reliable test, especially for those laboratories wishing to report anti-streptolysin $\mathbf{O}$ titres on the same day as the specimen is received, a service that is particularly welcomed by visiting clinicians.

References

Rantz, L. A., and Randall, E. (1945). A modification of the technique for determination of the anti-streptolysin titre. Proc. Soc. exp. Biol. (N. Y.), 59, 22-25.

Hoechst Pharmaceutical Laboratory Notes (1971). Determination of ASO content by haemolysis inhibition, April 1971, pp. 21-29. 